\title{
The effect of entrepreneurial personality traits of undergraduates in the area of education of physical education and sports on the entrepreneurship tendency ${ }^{1}$
}

\author{
Mehmet Öztaş ${ }^{2}$ \\ Murat Kasımoğlu ${ }^{3}$ \\ Erkan Faruk Şirin ${ }^{4}$
}

\begin{abstract}
The aim of the study is to identify the existing situation of entrepreneurship, whose importance gradually increases for the last 20 years, among university students taking education in the area of education of physical education and sports; to study whether or not entrepreneurial personality traits (desire to succeed, resolution, practical intelligence, innovativeness, independence, selfconfidence) affect entrepreneurship tendency; and to try to identify the degree of this effect. The sample of the study consist of 610 students from the Departments of Physical Education Teaching, Coaching Education, and Sports Management, who receive undergraduate education in Collegeges of Physical Education and Sports in Karamanoğlu Mehmetbey, Niğde, Aksaray, and Erciyes Universities and Faculty of Sport Sciences, Gazi and Selcuk University. In the study, sociodemographic form as well as "Entrepreneurial Personality Traits Inventory" to identify entrepreneurial personality traits, and Entrepreneurship Education Inventory were utilized. As a result of the study, among entrepreneurial personality traits, other than the factors of innovativeness and independence, it revealed that entrepreneurial personality traits had an effect on entrepreneurship education. In addition, it was also identified that there was a positive directional significant relationship between entrepreneurial personality traits and entrepreneur education. As also understood from here, among the other elements (family, belief, culture, etc.) affecting entrepreneurship, entrepreneurial personality traits have an important place in terms of entrepreneurship education.
\end{abstract}

Keywords: Entrepreneurial personality traits, entrepreneurship tendency, high education institutes giving sports education

\footnotetext{
${ }^{1}$ This article was presented orally at $10^{\text {th }}$ International Conference In Physical Education, Sports And Physical Therapy November 18-20, 2016, Elazığ, Turkey.

${ }^{2}$ Lecturer, Erzincan University, School of Physical Education and Sports, moztas@erzincan.edu.tr

${ }^{3}$ Phd Student, Selçuk University, muratkasimoglu@arvenilac.com.tr

${ }^{4}$ Associate Professor, Selçuk University, Faculty of Sports Sciences, erkanfaruk@yahoo.com
} 
Öztaş, M., Kasımoğlu, M., \& Șirin, E. F. (2017). The effect of entrepreneurial personality traits of undergraduates in the area of education of physical education and sports on the entrepreneurship tendency. Journal of Human Sciences, 14(4), 4365-4382. doi:10.14687/ihs.v14i4.4918

\section{INTRODUCTION}

Although entrepreneurship enters economy literature, beginning from $18^{\text {th }}$ century, entrepreneur was little discussed in the literature and was mostly examined under the definition of firm (Yatkın and Ölmez, 2011). The word entrepreneur originates from the word "enterprender/entrepreneur" in French and refers to "being responsible for something" or "promising to do something" (Gutiérrez and Guerrero, 2011). There are a number of definition attempts in the literature related to the concepts of entrepreneur and entrepreneurship (Meredith, Nelson, \& Neck, 1982; Senocak, 1992; Hinterhuber \& Popp, 1992; Titiz, 1994; Bull \& Willard, 1993; Çetin, 1996; Beatty, 1998; Çetindamar, 2002; Foss \& Klein, 2002; Kuratko \& Hodgetts, 2004; Cuervo, Ribeiro, \& Roig, 2007; Zucchella \& Scabini, 2007). In return to this, while many researchers define entrepreneurship, they view entrepreneurship as a problematic concept (Busenitz, et al., 2003). As a result of this, many researchers come to agreement about the definition of entrepreneurship and difficulty in forming and continuing the behaviors concerning entrepreneurship that are inherent in the entrepreneurship applications (Chell, 2008; Ahmetoglu, Leutner, \& Chamorro-Premuzic, 2011). The primary factor regarding that the concept entrepreneurship is problematic is commonly conceptualization of entrepreneurship as starting a business (Gartner, 1988). However, this concept does not cover all areas of entrepreneurship. Many researchers criticizes this definition due to its narrowness (McKenzie, Ugbah, \& Smothers, 2007).

Entrepreneurship can be defined as a process, in which the various resources and processes, are researched and assessed for individuals to utilize the certain opportunities (Shane \& Venkataraman, 2000). Among the common features of entrepreneurship, making profit (Hallak, Brown \& Lindsay, 2012), effectively evaluating the available resources conditions, and opportunities (Bayrakdar, 2011; Mueller \& Thomas, 2001), and carrying out creative and innovative activities (Beugelsdijk \& Noorderhaven, 2005; Hisrich \& Antoncic 2004; Jaafar, et al., 2011; Shaw, Loughlin, \& McFadzean, 2005; Thompson, 2002) take place.

There are many studies putting forward that entrepreneurship is a sort of activity appearing with the combinations of a number of personality traits. However, it is understood that many studies examining entrepreneurship until now include a certain common concepts in entrepreneurship traits. It is possible to put in order the traits commonly expressed in literature regarding entrepreneurship. Entrepreneurship is basically ability to discover, select, interpret opportunities and, later, to make innovation in uncertain environment. There are some main factors affecting this ability (Ferrante, 2005). These are need to succeed, control focus, tendency to take risk, tolerance to uncertainty, self-confidence, and innovativeness (Koh, 1996).

Of these factors, need to succeed, according to the suggestion made by McClelland (1961), puts forward that need for success is a factor affecting entrepreneurship behaviors. Need to succeed, as an important factor affecting entrepreneurship, expresses desire to do better one for being able to reach personal success. In addition, achievement motivation, which has a critical importance, for economic development, economic improvement, and businesses to grow, is one of the most prevalent determiners of entrepreneurship (Pillis \& Reardon, 2007). That the people, whose need to success, are more willing in the direction of being able to reach success leads their entrepreneurship tendencies to be higher (Koh, 1996; Poon, Ainuddin, \& Junit, 2006).

Control focus is a variable reflecting in what way the person perceives the connection power between his/her own actions and the results of these actions (Zhao \& Chen, 2008). According to another definition, control focus represents the belief of a person about whether or not he/she can control his/her perceptions about life and events in the life (Di Zhang \& Buring, 2011). In addition, chance or environmental factors and personally taking initiative express the degree of individuals to perceive the success and failure (Lau \& Shaffer, 1999). Starting a new business and sustaining it requires to consider that you can enable things to go just as you desire. Besides that entrepreneur has a vision, it is necessary for him/her to make a plan for becoming successful in that vision, and to believe in that vision (Soysekerci \& Akatay, 2004). 
Öztaş, M., Kasımoğlu, M., \& Șirin, E. F. (2017). The effect of entrepreneurial personality traits of undergraduates in the area of education of physical education and sports on the entrepreneurship tendency. Journal of Human Sciences, 14(4), 4365-4382. doi:10.14687/jhs.v14i4.4918

Risk taking, which takes place among the most important entrepreneurship traits, includes to make a decision without knowing what the results will be or in unknown conditions (Soysekerci \& Akatay, 2004). Entrepreneurship actions inherently include risk and uncertainty. First of all, the decision to become entrepreneur is risky compared to the other alternatives. According to Kraus (2013), risk taking deals with the activities, which may bring big opportunities and big failures at either personal or organizational level. According to many studies carried out, there is a positive correlation between becoming entrepreneur and risk taking (Calendo \& Kritikos, 2011). Norton Jr. \& Moore (2006), in the study they carried out, suggested that ability to take a risk is an important trait of entrepreneurs and that those becoming entrepreneur took more risk compared to those not becoming entrepreneur. According to the theory of entrepreneurship forming in $20^{\text {th }}$ century, entrepreneurship is a work of making innovation, taking risk.

An uncertain case is a case, which cannot be completely structured or categorized by individual due to lack of sufficient data, while uncertainty tolerance is ability to react negatively. This uncertainty refers to showing a high tolerance about the decision made in an uncertain environment without searching for more information. Uncertain tolerance enables individuals to find the creative and new ways with high tolerance (Teoh \& Foo, 1997). There is an uncertainty, when there is not enough information for a case. When a new business is started, uncertainty has a large effect on the individuals. When entrepreneurs face uncertainty and difficulties, they have to be insistent in their efforts (Wu, Matthews, \& Dagher, 2007).

Self-confidence expresses the belief, which will provide to cope with responsibility in this work, when entrepreneur are engaged in a new business activity, and thus, the one regarding which they have to ability they need (Bowman, 1999). Self-confidence enabling entrepreneur to be well motivated largely affects performance as well. Entrepreneurs face to the numerous difficulties and uncertainties in their businesses; hence, their self-confidence affect the abilities of entrepreneur to cope with these conditions (Hallak, Brown, \& Lindsay, 2012). Entrepreneurs have feeling of confidence about that they can overcome the problems that can emerge and cannot be predicted (Soysekerci \& Akatay, 2004).

Innovativeness is a factor that is effective on new business activities. In the literature, entrepreneurship is mostly associated with innovativeness (Covin \& Slevin 1991; Knight, 1997; Zahra, 1995). Karimi et al. (2011) expressed entrepreneurship as forming new products, services, processes, technologies, and work models and emphasizing the developments in technology. Brenkert (2009) also defines innovation as the fact that firm supports new thoughts aiming to develop new product and service and encourages creative processes. Innovation has gained importance at the level with entrepreneurship. Entrepreneur generates the changes and creates awareness via innovation, and as a result of this, reaches success (İscan \& Kaygin, 2011).

Entrepreneurship tendency expresses the predisposition of individual in the direction of making a new attempt (Chen \& Hsu 2013; Chelariu et al., 2008; Wiklund \& Shepherd, 2005). When it is considered in terms of businesses, entrepreneurship tendency shows the predisposition of top management to being able to undertake calculated risks, do innovation, and exhibit non-proactive behaviors (Todorovic, McNaughton, \& Guild, 2011). Therefore, entrepreneurship tendency generally makes a reference to top management strategy about innovativeness, proactivity, and risk taking (Chen \& Hsu, 2013; Chelariu et al., 2008; Kraus, 2013; Covin \& Slevin, 1991; Poon, Ainuddin, \& Junit, 2006). When entrepreneurship tendency is considered in terms of university students, we come to the concept of potential entrepreneur. Potential entrepreneur is used to define for people to have the traits, skills, and desires, which can direct them to entrepreneurship behavior (Chelariu et al., 2008).

Beginning from childhood until the end of adulthood stage, each of the factors being effective on the development of person is also effective in entrepreneurship. These factors affecting entrepreneurship and determining the decisions of people whether or not to become entrepreneur can be expressed as psychological, social and economic factors such as family support, financing 
Öztaş, M., Kasımoğlu, M., \& Șirin, E. F. (2017). The effect of entrepreneurial personality traits of undergraduates in the area of education of physical education and sports on the entrepreneurship tendency. Journal of Human Sciences, 14(4), 4365-4382. doi:10.14687/jhs.v14i4.4918

opportunities, government supports, raising, and education (Arrkan, 2004). Even the studies researching how an accurate entrepreneur soul emerges revealed that socio- biological factors job, religious past, maturing as well as education, and gender were effective in emergence of entrepreneurship. In this context, it is considered that education, especially provided in universities, was important in affecting the viewpoint of young people to entrepreneurship. Studies have shown that entrepreneurship education programs contribute to the development of entrepreneurial intentions (Küttim et al., 2014). It is seen that many countries including England (Jones \& Iredale, 2010), French (Klapper, 2004), German, Poland (Jones et al., 2011; Packham et al., 2010), Spain (Lanero et al., 2011), Italy (Dubbini \& Iacobucci, 2004), Indonesia (Utami, 2017), Ghana (Dzisi \& Odoom 2017) are trying to pursue entrepreneurship education especially at the level of bachelor's degree. Because, universities are considered as institutions playing a big role in obtaining both economic and social benefits thanks to their great capacity in both obtaining and disseminating knowledge (Vazquez et al., 2010).

While a number of study toward measuring the entrepreneurial personality traits (Koh,1996; Uygun, Mete, \& Güner, 2012; Karasakal, Aksu, \& Demircili, 2013; Bozkurt \& Erdurur, 2013; Tays1 \& Canbaz, 2013; Solmaz et al., 2014; Demireli et al., 2014; Nurluöz \& Esmailzadeh, 2017) and entrepreneurship tendencies (Guerrero, Rialp, \& Urbano, 2008; Balaban \& Özdemir, 2008; Doğaner \& Altunoğlu, 2010; Yüzüak, 2010; Tong, Tong, \& Loy, 2011; İşcan \& Kaygın, 2011; Gasse \& Tremblay, 2011; Bilge \& Bal, 2012; Çesteneci, 2012; Moriano et al., 2012; Öneren, 2012; Yıldız \& Kapu, 2012; Kılıç, Keklik, \& Çalış, 2012; Doğan, 2013; Arrighetti et al., 2013; Çelik, İnce, \& Bozyiğit, 2014; Özdemir, 2015; Doğan, 2015; Akman \& Bektaş 2017) of the students attract attention in the literature, it was seen that the studies carried out toward the entrepreneurial personality traits and entrepreneurship tendencies of the students taking education of physical education and sports (Şeşen \& Basım, 2012; Geri, 2013; Türkmen \& İşbilir, 2015; Demir et al., 2015) were rather limited. However, Ratten (2010), in his study, in which he aimed to develop sports-based entrepreneurship theory, when the day-to-day changing desires of consumers and innovation making, one of the most important traits of entrepreneurship, are considered, states that sports created an important sector in terms of entrepreneurship. Borgese (2007) mentions about the deficiency of researchers related to sports entrepreneurship, although the studies carried out on entrepreneurship are sample.

Today, when the importance of the contribution of entrepreneurship to the economy, development, and country welfare is noticed, in parallel with this, the rapidly growing structure of sports sector, attracts attention in terms of eating-drinking, entertainment, accommodation, performance products, technological developments, and sportive products, including production volume. That over 100 sports branches are existent and that they are assessed by the criteria such as age, gender, and weight, professionalism, and participation levels increase the diversity of sportive activities. This diversity increases the opinions that can be produced in terms of entrepreneurship. The growing structure of sports sector every passing day also accompany professionalism and institutionalism in sports management and sports organizations come to a compatible position with the other organizations. Together with those reported above, sports entrepreneurs only consist of the owners of professional sports institutes. Sports industry requires the diversity of large and small sized sub businesses. For example, owners of health clubs, operators of gymnasiums and facilities, league owners/operators, owners of sportive product store, ticket agents, and specialists of physical treatment are only some of these (Ekmekçi \& İrmiş, 2013).

These developments in sports industry mean that the entrepreneurs in sports area will be more needed. It is possible to express that the importance of institutes providing education of physical education and sports and students taking education of physical education and sports will also increase in parallel with the development of sports industry. This case is the sign of those entrepreneurs will be significantly needed in this area in terms of making and developing the necessary investments in sports area. In the institutes providing education of physical education and 
Öztaş, M., Kasımoğlu, M., \& Șirin, E. F. (2017). The effect of entrepreneurial personality traits of undergraduates in the area of education of physical education and sports on the entrepreneurship tendency. Journal of Human Sciences, 14(4), 4365-4382. doi:10.14687/jhs.v14i4.4918

sports, in the recent years, sports entrepreneurship is given as a course and it is seen that the courses of entrepreneurship take place in curriculums selectively (Borgese, 2007; Borgese, 2010; Türkmen \& İşbilir, 2015). In these courses, the role and importance of sports in the development of entrepreneurship traits and providing the expected benefits from entrepreneurship are attempted to be given.

The students having the education of physical education and sports can also be expressed as the applicants of manager and entrepreneur application of sport industry in the near future. For these reasons, in the development of entrepreneurial traits and providing the expected benefits from entrepreneurship, the role and importance providing the education of physical education and sports should not be ignored. Therefore, identifying the entrepreneurial personality traits of the students taking the education of physical education and sports and developing their entrepreneurship tendencies has importance in terms of the future of sports education. In this direction, identifying whether or not the entrepreneurial personality traits of the undergraduates taking physical education and sports affect entrepreneurship tendency forms the main subject of this study.

Study Model and Hypotheses

The original model of our study consists of 1 dependable variable and 6 independent variables. The model regarding factors is as follows.

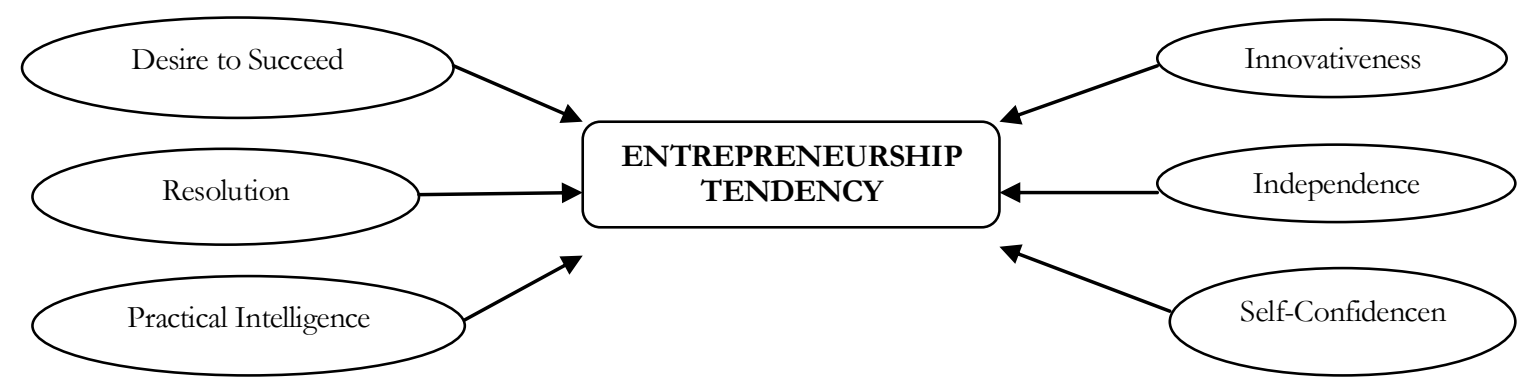

When the literature related to entrepreneurship is examined, the most frequently emphasized subjects as entrepreneurial personality trait are desire (ambition) to succeed, resolution, practical intelligence (creativity), innovativeness, independence, and self-confidence. Hypotheses, which aims to measure the entrepreneurship tendency of sample mass, developed by considering the assumption that the people having these traits can be engaged in more entrepreneurial activity, in addition, taking into consideration the effect of the frequently emphasized entrepreneurial personality traits on entrepreneurship tendency, are as follows.

Need to succeed prompts the people to entrepreneurship and contribute to the determination of aims (Korkmaz, 2012). According to McClallend (1961), need to succeed, known as a strong factor affecting the behaviors of the people, plays a key role in individuals' acting the desirable and resolute, while being engaged in entrepreneurial activities (Koh, 1996). In the direction of this information $\mathrm{H}_{1}$ hypothesis is formed as follows.

$\mathrm{H}_{1}$ : Desire to succeed, among entrepreneurial personality traits, has effect on entrepreneurship tendency.

Resolution is the leading traits that entrepreneurial people have to have. The reason for this is that entrepreneurial individuals go toward their targets and, for this aim, undertaking risk, bring together production factors (Solmaz et al., 2014). In the direction of this information, $\mathrm{H}_{2}$ hypothesis is formed as follows

$\mathrm{H}_{2}$ : Resolution, among entrepreneurial personality traits, has effect on entrepreneurship tendency.

Nicholas Baudeau, in his analysis related to entrepreneurship, emphasized the importance of ability and underlined the importance of intelligence, ability of entrepreneur to collect and 
Öztaş, M., Kasımoğlu, M., \& Șirin, E. F. (2017). The effect of entrepreneurial personality traits of undergraduates in the area of education of physical education and sports on the entrepreneurship tendency. Journal of Human Sciences, 14(4), 4365-4382. doi:10.14687/jhs.v14i4.4918

process information. Intelligence and information enables entrepreneur to control and measure (Hebert \& Link, 2006). In the direction of this information, $\mathrm{H}_{3}$ hypothesis is formed as follows $\mathrm{H}_{3}$ : Practical intelligence, among entrepreneurial personality traits, has effect on entrepreneurship tendency.

Peter Drucker, defining innovation as an useful information giving chance to the people, who work in an organization for the first time and have the different knowledge and ability for making them productive, stated that entrepreneurship is an action bestowing resources, which generate a new capability to form mediator and welfare (Durna, 2002). In the light of this information, $\mathrm{H}_{4}$ hypothesis is as follows:

$\mathrm{H}_{4}$ : Innovativeness, among entrepreneurial personality traits, has effect on entrepreneurship tendency.

One of the main reasons for becoming entrepreneur is to desire to be boss of his/her own business i.e. need for independence. Independence expresses to be able to act and make decision freely (Erdoğan, 2009). Desire to be independent is driving force behind modern entrepreneurs (Kuratko \& Hodgetts, 2009) In the light of this information, $\mathrm{H}_{5}$ hypothesis is as follows:

$\mathrm{H}_{5}$ : Independence, among entrepreneurial personality traits, has effect on entrepreneurship tendency.

When entrepreneurs are engaged in a new business activity, self-confidence, which expresses the belief they can cope with this business, thus, that this ability is existing within themselves, is known a symbol of success (Bowman, 1999; Lamping \& Kuehl, 2003). In the light of this information, $\mathrm{H}_{6}$ hypothesis is as follows:

$$
\mathrm{H}_{6} \text { : Self-confidence, among entrepreneurial personality traits, has effect on entrepreneurship tendency. }
$$

\section{METHOD}

In the scope of this study, in order to identify whether or not the entrepreneurial personality traits (desire to succeed, resolution, practical intelligence, innovativeness, independence, self-confidence) of university students taking undergraduate education in the area of education of physical education and sports affects entrepreneurship tendency and the degree of this effect, relational scanning model was used in the scope of quantitative paradigm. The study examining the relationships and connections is mostly called relational study (Büyüköztürk et al., 2013). The relational studies are the studies aiming to identify the presence and/or degree of covariation between two or more variables (Karasar, 2009).

\section{Universe and Sample}

The universe of the study consists of the students taking undergraduate education in the Schools of Physical Education and Sports of Karamanoğlu Mehmetbey, Niğde, Aksaray, and Erciyes Universities and Faculty of Sport Sciences, Gazi and Selçuk University. As of 2016, 77 universities have higher education institutions that provide physical education and sports education in Turkey (ÖSYS, 2016). Of these, 16 are located in the Central Anatolia Region and constitute the universe of the researcher. While the sample of the study consists of totally 610 students, voluntarily participated in the study from the six departments of physical education teaching, coaching education, and sport management and selected by convenience sample method, who take undergraduate education in the relevant colleges and faculties in the educational year of 2015 -2016. Convenience sampling method is a method, in which each element in the defined universe has equal and independent chance for being selected and the others are not also impeded (Altunissk et al., 2007). In this direction, considering the elements of both easy accessibility and being able to represent universe, in the different days, majority of the students are present in the school, 750 questionnaires were distributed and, as a result of that some students are absent and some of them do not want to complete questionnaire, of the questionnaires, only 610 were healthily returned and subjected to analysis. 
Öztaş, M., Kasımoğlu, M., \& Şirin, E. F. (2017). The effect of entrepreneurial personality traits of undergraduates in the area of education of physical education and sports on the entrepreneurship tendency. Journal of Human Sciences, 14(4), 4365-4382. doi:10.14687/jhs.v14i4.4918

Table 2 .

Demographic features of those participating in the study were presented in Table 1 and

Table 1. Demographic features of the students participating in the study

\begin{tabular}{lcc}
\hline Variables & Frequency & $\begin{array}{c}\text { Percentage } \\
\mathbf{( \% )}\end{array}$ \\
\hline Gender & 223 & 36.6 \\
Female & 387 & 63.4 \\
Male & & 20.5 \\
\hline Age & 125 & 74.4 \\
Ages 17-21 & 454 & 5.1 \\
Ages 22-26 & 31 & 18.7 \\
Age 26 and over & 114 & 11.0 \\
\hline University & 67 & 22.8 \\
Selçuk Uni. & 139 & 13.9 \\
Karamanoğlu Mehmetbey Uni & 85 & 25.4 \\
Niğde Uni & 155 & 8.2 \\
Aksaray Uni & 50 & 36.7 \\
Erciyes Uni & & 33.6 \\
Gazi Uni & 224 & 29.7 \\
\hline Department & 205 & 71.5 \\
Physical Education and Sports Education & 181 & 28.5 \\
$\quad$ Coaching Education & & $\mathbf{1 0 0 . 0}$ \\
\hline Sports Management & 436 & 174 \\
\hline Teaching Unit & $\mathbf{6 1 0}$ & \\
Daytime Education & & \\
Evening Education & & \\
\hline Total & & \\
\hline
\end{tabular}

When the values in Table 1 are examined, $36.6 \%$ of those participating in the study are female and $63.4 \%$ are male. It is understood that the students participating in the study are predominantly in the range of the ages 22-26. According to the distribution of university, in which the students study, the highest participation $(25.4 \%)$ is from Erciyes University. The distributions of the students of Physical Education and Sports Teaching, Coaching Education, and Sports Management are close to each other. About two-thirds (71.5\%) of these students study in the daytime education

Table 2. The other features regarding the students participating in the study

\begin{tabular}{|c|c|c|}
\hline Variables & Frequency & $\begin{array}{l}\text { Percentage } \\
(\%)\end{array}$ \\
\hline \multicolumn{3}{|c|}{ Sector wanted to work after graduation } \\
\hline Public Sector & 439 & 72.0 \\
\hline Private Sector & 94 & 15.4 \\
\hline Family Work & 19 & 3.1 \\
\hline My own business & 58 & 9.5 \\
\hline \multicolumn{3}{|c|}{$\begin{array}{l}\text { Did anyone from your family establish and manage } \\
\text { his/her own work? }\end{array}$} \\
\hline Yes & 319 & 52.3 \\
\hline No & 291 & 47.7 \\
\hline \multicolumn{3}{|c|}{$\begin{array}{l}\text { Did you work earlier in any job? (other than } \\
\text { internship) }\end{array}$} \\
\hline Yes & 510 & 83.6 \\
\hline Non & 100 & 16.4 \\
\hline \multicolumn{3}{|c|}{ Where did a large part of your life pass? } \\
\hline Village & 65 & 10.7 \\
\hline Town & 42 & 6.9 \\
\hline District & 140 & 23.0 \\
\hline City & 363 & 59.4 \\
\hline
\end{tabular}


Öztaş, M., Kasımoğlu, M., \& Șirin, E. F. (2017). The effect of entrepreneurial personality traits of undergraduates in the area of education of physical education and sports on the entrepreneurship tendency. Journal of Human Sciences, 14(4), 4365-4382. doi:10.14687/ihs.v14i4.4918

\begin{tabular}{|c|c|c|}
\hline \multicolumn{3}{|l|}{ Type of family, in which you grow } \\
\hline Elementary Family & 432 & 70.8 \\
\hline Large Family & 178 & 29.2 \\
\hline \multicolumn{3}{|c|}{$\begin{array}{l}\text { If you decide to establish their own business in the } \\
\text { future, at first, which fund resource do you think of } \\
\text { utilizing? }\end{array}$} \\
\hline I use my personal accumulations & 265 & 43.4 \\
\hline I utilize commercial credits & 167 & 27.4 \\
\hline I refer to my relations and family & 117 & 19.2 \\
\hline I work with one or several partners & 61 & 10.0 \\
\hline Total & 610 & 100.0 \\
\hline
\end{tabular}

The students participating in the study responded the question regarding sector, in the way they are going to prefer after graduation as "public sector" with $72.0 \%$ and "private sector" with $\% 15.4$ It was identified that the responses given to the question "Did anyone from your family establish and manage his/her own work?" showed close distribution to each other. 86.3\% responded positively the question "Did you work earlier in any job? (other than internship)". While majority (59.4\%) of those participating in the study spend a large part of their lives in the cities, their majority $(70.8 \%)$ determined the type, in which they grow as elementary family. When the answers given to the question "If you decide to establish their own business in the future, at first, which fund resource do you think of utilizing?" are examined, it was identified that the most of the students would use their personal accumulations (43.4\%) and, later, this was followed by the answer "they would utilize commercial credits" (27.4\%).

\section{Data Collecting Instruments}

In the study, together with "Sociodemographic Form", "Entrepreneurial Personality Traits Inventory" was utilized to identify entrepreneurial personality traits and "Entrepreneurship Tendencies Inventory" to identify entrepreneurship tendencies.

\section{Sociodemographic Form}

In the study, in order to identify socio-demographic feature of the students, 11 questions considered that they are related to the subject, were formed by making certain definitions.

\section{Entrepreneurial Personality Traits Inventory}

Entrepreneurial Personality Traits Inventory is an inventory developed by Solmaz, Aksoy, Şengül, Sarışı1k (2014). Inventory consists of 22 expressions. It is type of 5-point Likert, in which "1 = I definitely disagree with it", " 2 = I partly disagree with it", "3 = I am indecisive", "4 = I partly agree with it", and " $5=$ I definitely agree with it". The value of Cronbach alpha regarding inventory was found as 0.868 . In explanatory factor analysis, carried out by Solmaz et al (2014), factor loads of 22 expressions taking place in personality traits inventory were found between $0.582-0.817$; KMO (Kaiser-Meyer-Olkin), 0.897; and Bartlett test, significant $(\mathrm{p}<0.001)$. Total variance, explained by 6 dimensions emerging regarding entrepreneurial personality traits of the students, is $63.08 \%$. Six factors obtained emerged as "desire to succeed", "resolution", "practical intelligence (creativity)", "innovativeness", "independence", and "self-confidence".

\section{Entrepreneurship Tendency Inventory}

Entrepreneurship Tendency Inventory is an inventory whose original was developed by Girginer and Uçgun (2004). Inventory consists of 14 expressions. It is type of 5-point Likert, in which " 1 = I definitely disagree with it", " 2 = I partly disagree with it", " $3=$ I am indecisive", " 4 = I partly agree with it", and " $5=$ I definitely agree with it".

The values of Cronbach alpha in the previously carried out studies regarding the inventory were found " $\alpha=0.89$ " by Girginer and Uçgun (2004); " $\alpha=0.76$ ” by Bozkurt and Erbudur (2013); 
Öztaş, M., Kasımoğlu, M., \& Şirin, E. F. (2017). The effect of entrepreneurial personality traits of undergraduates in the area of education of physical education and sports on the entrepreneurship tendency. Journal of Human Sciences, 14(4), 4365-4382. doi:10.14687/jhs.v14i4.4918

and " $\alpha=0.86$ ", by Akyüz, Gedik, Aydın, Yıldırım and Akyüz (2009). In the explanatory factor analysis, carried out by the researcher, factor loads of 14 expressions taking place in entrepreneurship tendency inventory were found between 0.704-0.876; KMO (Kaiser-MeyerOlkin), 0.787; the result of Bartlett test 2107.149; and reliability of inventory (Cronbach alpha), 0.82. As a result of analyses carried out, it is seen that inventory can be applicable in the direction of the aim of the study. .

\section{Data Collecting and Analysis}

After the necessary permissions are taken from the heads of department for administering personal information form and inventories, the data were obtained by administrating them to the students in course breaks. Before inventories were administered, the necessary explanations were made by the researcher. Responding data collecting instruments takes about 15 minutes. After the forms completed missing or wrong are checked, 610 forms those are valid and in acceptable quality were made ready for analyses.

In the stage of analyzing data, in accordance with the aims of the study, frequency and percentage distributions were sorted out, which are descriptive of personal traits of the students. Shapiro- Wilk Test was applied in order to decide whether the questionnaires were suitable to normal divisions and parametric tests were applied because normal divisions were available. In order to evaluate the relationship between variables, correlation (Pearson) and regression analyses were made. The data obtained were analyzed on SPSS (Statistical Package for Social Scientists for Windows Release 20,0) in computer and their significance were tested at the level of 0.05.

\section{RESULTS}

In this direction, averages regarding variables, correlation and regression analyses regarding variables, hypotheses formed in the scope of study, and questions regarding the study.

Table 3. Correlation and Descriptive Statistics Analysis Belonging to the Relationship between Entrepreneurial Personality Traits and Entrepreneurship Tendencies of the Students

\begin{tabular}{|c|c|c|c|c|c|c|c|c|c|}
\hline & Mean & SD & 1 & 2 & 3 & 4 & 5 & 6 & 7 \\
\hline 1.Entreprenership Tendency & 3,47 & 59 & 1 & & & & & & \\
\hline 2. Desire to Success & 4,11 & ,85 &, $387^{* *}$ & 1 & & & & & \\
\hline 3. Resolution & 4,30 &, 77 &, $382^{* *}$ &, $694^{* *}$ & 1 & & & & \\
\hline 4. Practical Intelligence & 4,01 & 82 &, $399^{* *}$ & $656^{* *}$ &, $743^{* *}$ & 1 & & & \\
\hline 5. Innovativeness & 4,29 &, 76 &, $303^{* *}$ &, $642^{* *}$ &, $733^{* *}$ &, $710^{* *}$ & 1 & & \\
\hline 6. Independence & 4,12 & 87 &, $321^{* *}$ &, $549^{* *}$ &, $632^{* *}$ &, $639^{* *}$ &, $674^{* *}$ & 1 & \\
\hline 7. Self-Confidence & 3,67 & ,96 &, $373^{* *}$ & $358^{* *}$ & $338^{* *}$ & $371^{* *}$ &, $333^{* *}$ &, $500^{* *}$ & 1 \\
\hline
\end{tabular}

When the values in Table 3 are examined, it is also seen that the students taking the education of physical education and sports agreed with all suggestions at high level from their mean scores. When mean scores are evaluated, resolution (4.30), innovativeness (4.29), independence, (4.12) desire to succeed (4.11) and practical intelligence (4.01), among entrepreneurial personality traits of the students, are in the direction of "I definitely agree with it" with the highest averages. However, the students informed view in the direction of "I agree with it" (3.67) to the variable of "self-confidence", among entrepreneurial personality traits In addition, their entrepreneurship tendencies are in the direction of "I agree with it" with the mean score of 3.48. The values of correlation in the table are examined, it is seen that there is a relationship between dependable and interdependent variables. It revealed that there was a positive directional, significant, and middle level relationship between entrepreneurship tendency and the factors of desire to success (.387), resolution (.382), practical intelligence (.399), independence (.321), and self-confidence (.373), among entrepreneurial personality traits; and there was a positive directional bur low level 
Öztaş, M., Kasımoğlu, M., \& Șirin, E. F. (2017). The effect of entrepreneurial personality traits of undergraduates in the area of education of physical education and sports on the entrepreneurship tendency. Journal of Human Sciences, 14(4), 4365-4382. doi:10.14687/jhs.v14i4.4918

relationship between entrepreneurship tendency and innovativeness (.303), entrepreneurial personality trait.

Table 4. Regression Model Made to Test the Effect of Entrepreneurial Personality Traits on Entrepreneurship Tendency

\begin{tabular}{|c|c|c|c|c|c|c|c|}
\hline Dependable Variable & Independent Variables & $\beta$ & $\mathrm{t}$ & $\mathrm{p}$ & $\mathrm{F}$ & $\mathrm{p}$ & $\mathrm{R}^{2}$ \\
\hline Entrepreneurship & (Fixed) & & 14,186 & ,000 & & & \\
\hline \multirow[t]{6}{*}{ Tendency } & Desire to Succeed & ,156 & 2,963 & ,003 & & & \\
\hline & Resolution & ,138 & Table & ,028 & & & \\
\hline & Practical Intelligence & ,191 & 3,207 & ,001 & 32,161 &, 000 & ,242 \\
\hline & Innovativeness &,- 091 & $-1,527$ & ,127 & & & \\
\hline & Independence &,- 036 &,- 665 &, 507 & & & \\
\hline & Self-Confidence & 248 & 6,009 &, 000 & & & \\
\hline
\end{tabular}

When the values in Table 4 are examined, it is seen that the independent variables entered into the model significantly predicted the dependent variable of the entrepreneurship tendency $\left(\mathrm{R}^{2}=, 24 ; \mathrm{F}=32,161 ; \mathrm{p}=0,000<0,05\right)$. With a joint effect, desire to succeed, resolution, practical intelligence, innovativeness, independence, and self-confidence explained $24 \%$ of the total variance in entrepreneurship tendency. On the other hand, innovativeness, and independence alone had no significant effect on the scores from the entrepreneurship tendency. The regression equation for the model is as follows; entrepreneurship tendency $=1,879+0,11 \mathrm{X}$ Desire to Succeed $+0,10 \mathrm{X}$ Resolution $+0,14 \mathrm{X}$ Practical Intelligence $+(-0,07) \mathrm{X}$ Innovativeness $+(-0,03) \mathrm{X}$ Independence $+0,15$ Self-Confidence. Hypothesis 1, Hypothesis 2, Hypothesis 3, and Hypothesis 6 was supported.

\section{DISCUSSION AND CONCLUSION}

This study was realized to reveal the effect of entrepreneurial personality traits of the university students taking undergraduate education in the area of education of physical education and sports on entrepreneurship tendency and the relationship of entrepreneurial personality traits with entrepreneurship tendency.

As a result of the mean values belonging to entrepreneurial personality traits (desire to succeed, resolution, practical intelligence, innovativeness, independence, self-confidence), it emerged that the participants generally had entrepreneurial personality traits. It can be said that that participants take entrepreneurship education, that they make obligatory internship due to the department they study, and thanks to this, that they acquire business experience provide important contributions to the emergence of entrepreneurship potential of the mass.

As a result of correlation analysis made to measure the relationship between entrepreneurial personality traits and entrepreneurship tendency, it revealed that there was a positive directional, significant, and middle level relationship between entrepreneurship tendency and the factors of desire to access, resolution practical intelligence, independence, and self-confidence, among entrepreneurial personality traits; and there was a positive directional bur low level relationship between entrepreneurship tendency and innovativeness, entrepreneurial personality trait. According to this, it was concluded that the tendency of young entrepreneur applicants to become entrepreneur in the future also increases. As these personality traits increase. The general view in the literature is in the direction that, individuals having entrepreneurial personality traits can be desirable and resolute about being engaged in entrepreneur activities and they can become successful entrepreneurs. The study by Bozkurt and Erdurur (2013), which supports our study results, suggested that for the students taking education of tourism undergraduate, the other entrepreneurial personality traits other than the factor of self-confidence had an effect on entrepreneurship tendency. In addition, it was identified that there was a positive directional 
Öztaş, M., Kasımoğlu, M., \& Șirin, E. F. (2017). The effect of entrepreneurial personality traits of undergraduates in the area of education of physical education and sports on the entrepreneurship tendency. Journal of Human Sciences, 14(4), 4365-4382. doi:10.14687/jhs.v14i4.4918

significant relationship between entrepreneurship tendency and entrepreneurial personality traits. In the study by Uygun Mete, \& Güner (2012), which partly supports our study results, it was identified that there was a significant relationship between only the traits of self-confidence and risk taking, among personality traits of university students, and entrepreneurship tendency. In addition, in the study, in which Yildız \& Kapu (2012) examined the relationship between individual values of university students and their entrepreneurship tendencies, it was concluded that the individual value, which was in a relationship that is positive directional and at the highest level was "power and success", while individual value in a relationship that is in negative direction was "traditionalism".

In this study, it was seen that as a result of regression analysis belonging to the effect of entrepreneurial personality traits on entrepreneurship tendency, entrepreneurial personality features has an effect of $24 \%$ on entrepreneurship tendency. There are many factors (family, culture, role models, belief, age, gender, income, education, job experience, environment, technology, and entrepreneurial personality traits) affecting entrepreneurship. When all of these factors are considered, that only entrepreneurial personality traits have an effect of $24 \%$ on entrepreneurship tendency reveals the fact that this rate is not less. But in terms of the case that the entrepreneurial tendencies of the students are affected from their entrepreneur personality traits, while the entrepreneurial personality traits of desire to success, resolution, practical intelligence, and selfconfidence has a significant effect, any effect of entrepreneurial personality traits of innovativeness and independence on entrepreneurship tendency could not be identified. In other words, among entrepreneurial personality traits, as the traits of desire to success, resolution, practical intelligence, and self- confidence increase, the tendency of the students to become entrepreneur in the future also increases; however, the same increase is out of question in terms of the other entrepreneurial personality traits (innovativeness, self -confidence). In the study by Bozkurt \& Erdurur (2013) supporting our study results, according to the case that the entrepreneurship tendencies are affected from their entrepreneur personality traits, while risk taking, innovativeness, entrepreneurial personality traits of need to succeed, control focus, and tolerance to uncertainty significantly affect entrepreneurship tendency, any effect of entrepreneurial personality trait of self-confidence on entrepreneurship tendency could not be identified. In addition, in the study, it was identified that entrepreneurial personality traits had an effect of $28 \%$ on entrepreneurship tendency.

$\mathrm{H}_{1}$ hypothesis, formed in the form of "desire to succeed, among entrepreneurial personality traits, has effect on entrepreneurship tendency" was accepted. Success need is a factor directing entrepreneurship behavior. An individual having high success need feels confident, enjoys taking calculated risks, takes delight from actively researching his/her environment, and researches how he/she will do better something he/she does (Kaya, Güzel, \& Çubukçu, 2011). According to Mc Clelland (1961), high success motive is an important factor affecting entrepreneurship behaviors. Especially, need to success prompts the people to entrepreneurship and makes a contribution to determining the aims (Korkmaz, 2012). The results that turn out are supported by the view that success motive in the literature was seen as a big psychological factor, which emphasizes stability of individuals in reaching their targets, and that successful entrepreneurs are the people, who believe in their own abilities and undertake every kind of responsibility

$\mathrm{H}_{2}$ hypothesis, formed in the form of "resolution, among entrepreneurial personality traits, has effect on entrepreneurship tendency" was accepted. Resolution for entrepreneurs are defined as the power to be able to fearlessly struggle against difficulties they face (Demirel \& Akbiylk, 2009). Resolution is among the leading traits the entrepreneurial people have to have. The reason for this is that the entrepreneurial individuals go toward their targets and, for this aim, undertaking risk, that they bring together production factor (Solmaz et al., 2014). At this point, it is possible to say that getting a favorable result from enterprises i.e. entrepreneurship tendency will be possible with that entrepreneurial individuals have a resolute personality structure 
Öztaş, M., Kasımoğlu, M., \& Șirin, E. F. (2017). The effect of entrepreneurial personality traits of undergraduates in the area of education of physical education and sports on the entrepreneurship tendency. Journal of Human Sciences, 14(4), 4365-4382. doi:10.14687/jhs.v14i4.4918

$\mathrm{H}_{3}$ hypothesis, formed in the form of "practical intelligence, among entrepreneurial personality traits, has effect on entrepreneurship tendency" was accepted. Nicholas Baudeau, one of the authors developing entrepreneurship theory, in his analysis related to entrepreneurship, emphasized the importance of ability and underlined the importance of intelligence and ability of entrepreneur to collect and process knowledge and information. Intelligence and knowledge enable entrepreneur to control and measure (Hebert \& Link, 2006). There is implicit knowledge in the essence of practical intelligence gaining importance in the area of business management. Implicit knowledge is activity-focused information, which are obtained without any help of others and will enable individuals to reach the targets they value. The gain of this kind of knowledge is an important element in business life (Sternberg, 1997). Namely, being able to observe the changes around them, being able to create quick solutions of the problems and, depending on this, having an entrepreneurial tendency depend on that practical intelligence of students is high. The view about practical intelligence support this result that emerges

$\mathrm{H}_{4}$ hypothesis, formed in the form of "innovativeness, among entrepreneurial personality traits, has effect on entrepreneurship tendency" was rejected. Innovativeness is a tendency, which includes creating new products and new methods, accessing to new markets, establishing a new organizational structure, and introducing a will toward all of these (Keleş et al., 2011). Innovativeness is a case that can be seen especially in the existing businesses. That is, it can form with the support of top management in business. Therefore, entrepreneurship tendency generally refers to the strategy of top management about innovativeness (Poon, Ainuddin, \& Junit, 2006). Based on these explanations, it is possible to interpret that hat innovativeness does not affect entrepreneurship tendency can be due to the fact that sample mass consists of students.

$\mathrm{H}_{5}$ hypothesis, formed in the form of "independence, among entrepreneurial personality traits, has effect on entrepreneurship tendency" was rejected. One of the main causes of becoming entrepreneur is the desire to be the boss of his/her own boss i.e. independency need. Independence expresses to be able to act and decide freely (Erdoğan, 2009). Independence desire is driving force between contemporary entrepreneurs (Kuratko \& Hodgetts, 2009). Independence desire expresses to form an independent personality and carry out their own jobs without any bureaucratic pressure. Therefore, many researchers count independence desire among the characteristic features of an entrepreneur (Lamping \& Kuehl, 2003; Izedonmi \& Okafar, 2005; Kuratko \& Hodgetts, 2009; Mohanty, 2005; Schwarz et al., 2009). It can be possible to interpret this case in the way of that sample mass does not receive this education in their courses in applied way; that they want to work in public institutes as a result of that their undergoes training in public institutes; that they cannot predict the future and therefore working in any public institute or private sector does not take place in their lives; that there are many bureaucratic barriers the entrepreneur and entrepreneurial applicants wanting to establish their own businesses face; that educational system may not have brought independence in the individual; and that this also does not affect entrepreneurship tendency.

$\mathrm{H}_{6}$ hypothesis, formed in the form of "self-confidence, among entrepreneurial personality traits, has effect on entrepreneurship tendency" was accepted. Self-confidence expressing the belief that when entrepreneurs are engaged in a new business activity, they can cope with this business, and that they themselves have this ability is known as the symbol of success (Bowman, 1999; Lamping \& Kuehl, 2003). In the study by Bozkurt \& Erdurur (2013) supporting our study results, in terms of the case that entrepreneurship tendency is affected from entrepreneurial personality traits, it cannot be identified that self-confidence, among entrepreneur personality traits, did not have any effect on entrepreneurship tendency. In addition in the study carried out by Koh (1996) on 100 postgraduate students in Hong Kong, the conclusion that the individuals showed a high tendency at the point of self-confidence turned out. It is known that turning the new ideas into a business is a difficult process in terms of both cost and time and experience. In contrast to these study results, it can be reached the conclusion that sample mass taking place in the study by Koh 
Öztaş, M., Kasımoğlu, M., \& Şirin, E. F. (2017). The effect of entrepreneurial personality traits of undergraduates in the area of education of physical education and sports on the entrepreneurship tendency. Journal of Human Sciences, 14(4), 4365-4382. doi:10.14687/ihs.v14i4.4918

felt a great belief in their own abilities and experiences about this issue. Albeit the participants show a tendency about self-confidence, such a result may have turned out, since they consider that this will not be enough at the point of influencing entrepreneurship tendency and elements of external environment may also influence entrepreneurship tendency.

As a result, among the personality traits of students in the universities providing undergraduate education in the area of physical education and sports, it revealed that other than the factor of innovativeness and independence, the other entrepreneurial personality traits had an effect on entrepreneurship tendency. In addition, it was also identified that there was a positive directional and significant relationship between entrepreneurial personality traits and entrepreneurship tendency

In the family, where the personality first begin to develop, and in the school, where it continues to develop, in the social life, carrying out studies toward that people shape their personalities as entrepreneurship- inclined comes to our face as an important subject. That the support and educational program are become widespread in the schools, in addition, that educational institutes hold seminar can help the students' direct entrepreneurial activities. On the other hand, it can be suggested that educational institutes, acting together with the organizations presenting support, support individuals about showing tendency to entrepreneurship and their being engaged in entrepreneurial activities.

This study has been carried out on the students of six public universities, which are located in Central Anatolian Regions, providing undergraduate education in the area of physical education and sports. In the future studies, it can be suggested to carry out the studies by using the different study techniques in larger and more different universes. Thus, both effectiveness degree of the other elements affecting entrepreneurship on entrepreneurship tendency and the differences between the people in the different regions can be identified. This case can be useful in forming more sound decisions and plans regarding the subject.

\section{REFERENCES}

Ahmetoglu, G., Leutner, F., \& Chamorro-Premuzic, T. (2011). EQ-nomics: Understanding the relationship between individual differences in trait emotional intelligence and entrepreneurship. Personality and Individual Differences, 51, 1028-1033.

Akman, S. U., \& Bektaş, H. (2017). The effects of demographic characteristics of university students on entrepreneurial intentions. Research Journal of Politics, Economics and Management, 5(2), 309-318.

Akyüz, K. C., Gedik, T., Aydin, A., Yildirim, I., Akyüz, İ. (2009). Profession preference and entrepreneurship talent of senior men of faculty of forestry. International Journal of Economic and Administrative Studies, 2(1), 139-158.

Altunışık, R., Coşkun, R., Bayraktaroğlu, S., Yıldırım, E., (2010). Research methods in social sciences (with SPSS application) $\left(6^{\text {th }}\right.$ edition). Sakarya: Sakarya Publishing.

Arıkan, S. (2004). Girişimcilik temel kavramlar ve baž güncel konular. Ankara: Siyasal Kitabevi,

Arrighetti, A., Caricati, L., Landini, F., Monacelli, N. (2013). Explaining entrepreneurial orientation among university students: Evidence from Italy. C.MET Working Papers, 1-24.

Balaban, Ö., \& Özdemir, Y. (2008). Girişimcilik eğitiminin girişimcilik eğilimi üzerindeki etkisi: Sakarya üniversitesi iibf örneği. Girişimcilik ve Kalkenma Dergisi, 3(2), 133-147.

Bayrakdar, S. (2011). The Importance of entrepreneurship education within the EU vocational education programs concerning economic development. Cumhuriyet University, Journal of Economics and Administrative Sciences (JEAS), 12(1), 245-264.

Beatty, J. (1998). The world according to Peter Drucker. New York: Free Press.

Beugelsdijk, S., \& Noorderhaven, N. (2005), Personality characteristics of self-employed; An empirical study. Small Business Economics, 24, 159-167. 
Öztaş, M., Kasımoğlu, M., \& Șirin, E. F. (2017). The effect of entrepreneurial personality traits of undergraduates in the area of education of physical education and sports on the entrepreneurship tendency. Journal of Human Sciences, 14(4), 4365-4382. doi:10.14687/jhs.v14i4.4918

Bilge, H., \& Bal V. (2012). Girişimcilik eğilimi: Celal Bayar Üniversitesi öğrencileri üzerine bir araştırma. Süleyman Demirel Üniversitesi Sosyal Bilimler Enstitüsü Dergisi, 16, 131-148.

Brenkert, G. G. (2009). Innovation, rule breaking and ethics of entrepreneurship. Journal of Business Venturing, 24, 448-464.

Borgese A, (2007). Standarts in sports entrepreneurship education, Unpublished Doctoral's Thesis, United States Sports Academy, Brooklyn: New York.

Borgese, A. (2010). Educating sports entrepreneurs: matching theory to practice. The Sport Journal, 13(3).

Bowman, C. (1999). Action-Led strategy and managerial self-confidence. Journal of Managerial Psychology, 14(7/8), 558-568.

Bozkurt, Ö. \& Erdurur, K. (2013). The contribution of education to entrepreneurial sentiments: an example of Kütahya vocational school the department of machine. Journal of Entrepreneurship and Development, 8(2), 33-56.

Bull, I. \& Willard, G. E. (1993). Towards a theory of entrepreneurship. Journal of Business Venturing, 8(3), 183-195.

Busenitz, L.W., West III, G.P., Shepherd, D., Nelson, T., Chandler, G.N., \&Zacharakis, A. (2003). Entrepreneurship research in emergence: Past trends and future directions. Journal of Mana gement, 29(3), 285-308.

Büyüköztürk Ş, Kılıç EK, Akgün ÖE, Karadeniz Ş, Demirel F, 2013. Bilimsel araștrma yöntemleri. 18. Basım, Ankara: Pegem A Yayıncilik.

Caliendo, M. and Kritikos, A. S. (2012), Searching for the entreprenerial personality: new evidence and avenues for further research. Journal of Economic Psychology, 33(2), 319-324.

Chelariu, C., Brashear, T. G., Osmonbekov, T., \& Zait, A. (2008). Entrepreneurial propensity in a transition economy: Exploring micro-level and meso-level cultural antecedents, Journal of Business \& Industrial Marketing, 23(6), 405-415.

Chell, E., \& Baines, S. (2000). Networking, entrepreneurship and micro business behavior. Entrepreneurship and Regional Development, 12, 195-215.

Chen, H. L., \& Hsu, C. H. (2013). Entrepreneurial orientation and firm performance in non-profit service organizations: Contingent effect of market orientation. The Service Industries Journal, 33(5), 445-466.

Covin, J. G., \& Slevin, D. P. (1991). A conceptual model of entrepreneurship as firm behavior. Entrepreneurship Theory and Practice, 16, 7-25.

Cuervo, A., Ribeiro, D. \& Roig, S. (2007). Entrepreneurship - concepts, theory and perspective. Berlin: Heidelberg.

Çelik, A., İnce, M., Bozyiğit, S. (2014).Üniversite öğrencilerinin girişimcilik niyetlerini etkileyen ailesel faktörleri belirlemeye yönelik bir çalışma. Nï̆de Üniversitesi İktisadi ve İdari Bilimler Fakïltesi Dergisi, 7(3), 113-124.

Çesteneci, Y. (2012). The effects of immigration on the notion of entrepreneurial tendency. Unpublished Master's Thesis, Sakarya University Institute of Social Sciences.

Çetin, C. (1996). Yeniden yapılanma-girişimcilike ve kü̧̈üle ve orta boy işletmeler ve bunlarn özendirilmesi. İstanbul: Der Yayınlar1.

Çetindamar, D. (2002). Türkijye'de girişimcilik. Ankara: TUSİAD Yayınları.

Demir, A. Z., Eliöz, M., Çebi, M. ve Sezen, S. (2015). Girişimcilik ve girişimci üniversite: Spor fakültesi öğrencileri üzerine bir çalışma. Ondokuð Mayıs Üniversitesi Eğitim Fakültesi Dergisi, 34(1), 198-212.

Demirel, E. ve Akbıyık, N. (2009). Girişimcilik kavramı ve ortaya çıkışı. Tikici, M. ve Aksoy, A. (Eds.) Girişimcilik ve kü̧̈ük işletmeler, (pp. 5-67), Ankara: Nobel Yayın Dağıtım.

Demireli, C., Uluköy, M., Kahya, V., Demirăg, F. (2014). Farklı öğrenim düzeyindeki öğrencilerin girişimcilik özelliklerinin belirlenmesine yönelik bir alan araştırması. Manas Journal of Social Studies, 3(1), 1-17. 
Öztaş, M., Kasımoğlu, M., \& Şirin, E. F. (2017). The effect of entrepreneurial personality traits of undergraduates in the area of education of physical education and sports on the entrepreneurship tendency. Journal of Human Sciences, 14(4), 4365-4382. doi:10.14687/jhs.v14i4.4918

Dubbini, S., \& Iacobucci, D. (2004, July 4-7). The development of entrepreneurial competences: Entrepreneurship education in Italian universities and firms' organizational models. In Internationalizing Entrepreneurship Education and Training Conference, Naples.

Di Zhang, D., \& Bruning, E. (2011). Personal characteristics and strategic orientation: Entrepreneurs in Canadian manufacturing companies, International Journal of Entrepreneurial Bebaviour \& Research, 17(1),82-103.

Doğan, N. (2013). Entrepreneurship tendency in Turkey: A university students oriented research. Unpublished Doctoral's Thesis, İstanbul University Institute of Social Sciences.

Doğan, E. (2015). The effect of entrepreneurship education on entrepreneurial intentions of university students in Turkey. Ekonometri ve Istatistik Sayl, 23, 79-93

Doğaner, M. ve Altunoğlu, A. E. (2010). Adnan menderes üniversitesi nazilli iktisadi ve idari bilimler fakültesi işletme bölümü öğrencilerinin girişimcilik eğilimleri. Organizasyon ve Yönetim Bilimleri Dergisi, 2(2), 103-110.

Durna, U. (2002), Yenilik yönetimi. (1. Bask1), Ankara: Nobel Yayınları.

Dzisi, S., \& Odoom, F. (2017). Entrepreneurship education and training in higher educational institutions in Ghana. Journal of International Entrepreneurship, 1-17.

Erdoğan, B. Z. (2009). Girişimcilik ve kobiler teori ve uygulama. Bursa, Ekin Yayınc1lk.

Ekmekçi, Y. A. D., \& İrmiş, A. (17-18 September 2013). Entrepreneurshipand Sport, International Conference on Eurasian Economies, St. Petersburg: Russia.

Ferrante, F. (2005). Revealing entrepreneurial talent. Small Business Economics, 25,159-174.

Foss, N. J. and Klein P. G. (eds.) (2002). Entrepreneurship and the Firm: Austrian Perspective on Economic Organization, Edward Elgar.

Gartner, W. (1988). "Who is the entrepreneur?" is the wrong question. Retrieved from https://zabdesk.szabist.edu.pk/CoursePortFolioFiles/Mubin_1140_2758_1/who\%20is\%2 0an $\% 20$ ent $\% 20-\% 20$ lums.pdf

Gasse, Y., Tremblay, M. (2011). Entrepreneurial beliefs and intentions: A cross-cultural study of university students in seven countries. International Journal of Business, 16(4), 303-314.

Geri, S. (2013). Research on entrepreneurial characteristics of students in school of physical education and sports. Turkish Journal of Education, 2, 50-60.

Girginer, N ve Uçkun, N. (25-26 Kasım 2004). İsletmecilik eğitimi alan lisans öğrencilerinin girişimciliğe bakış açıları: Eskişehir Osmangazi üniversitesi I.I.B.F işletme bölümü öğrencilerine yönelik bir uygulama, 3. Ulusal Bilgi, Ekonomi ve Yönetim Kongresi, Eskișehir.

Guerrero, M., Rialp, J., Urbano, D. (2008). The impact of desirability and feasibility on entrepreneurial intentions: A structural equation model. International Entrepreneurship and Management Journal, 4(1), 35-50.

Gutierrez, A. R. C., \& Guerrero, A. B. (2011). Education and enterpreneurship: Educating in the new competence of autonomy and personel initiative. Internetional Journal of Learning. 18(8), 237-247.

Hallak, R., Brown, G., \& Lindsay, N. J. (2012). The place identity-performance relationship among tourism entrepreneurs: A structural equation modeling analysis. Tourism Management, 33 (1), 143-154.

Hebert R. F., \& Link, A. N. (2006). The entrepreneur as innovator. Journal of Technology Transfer, 31, 590.

Hinterhuber, H. H., \& Popp, W. (1992). Are you a strategist or just a manager?. Harvard Business Review, 105-113.

Hisrich, D. R. \& Antoncic, B. (2004). Corporate entrepreneurship contingencies and organizational wealth creation. Journal of Management Development, 23(6), 518-550.

İşcan, Ö. F., ve Kaygin, E. (2011). An investigation to determine the entrepreneurship tendency of university students. Journal of Graduate School of Social Sciences, 15(2), 443-462. 
Öztaş, M., Kasımoğlu, M., \& Șirin, E. F. (2017). The effect of entrepreneurial personality traits of undergraduates in the area of education of physical education and sports on the entrepreneurship tendency. Journal of Human Sciences, 14(4), 4365-4382. doi:10.14687/jhs.v14i4.4918

Izedonmi, F., \& Okafar, C. (2005). Assessment of the entrepreneurial characteristic and intentions among, Academic IFE Psycholog, 16(2), 153-168.

Jaafar, M. Abdul-Aziz, R. A. Maideen, A. S., \& Mohd, Z. S. (2011). Entrepreneurship in the tourism industry: Issues in developing countries. International Journal of Hospitality Management, 30(1), $827-835$.

Jones, B., \& Iredale, N. (2010). Enterprise education as pedagogy. Education + Training, 52, 7-19.

Jones, P., Miller, C., Jones, A., Packham, G., Pickernell, D., \& Zbierowski, P. (2011). Attitudes and motivations of Polish students towards entrepreneurial activity. Education + Training, 53, 416-432.

Karasakal, N., Aksu, B. ve Demircili, E. (2013). A Field study to determine the effect of programme type on encouraging the entrepreneurship and formation of entrepreneurial personality at the students of vocational high schools' technical and social programmes. Organizasyon Ve Yönetim Bilimleri Dergisi, 5(2), 134-150.

Karasar, N. (2009). Bilimsel arasttrma yöntemi, Ankara: Nobel Yayın Dağıtım.

Karimi, A., Malekmohamadi, I., Daryani, A. M., \& Rezvanfar, A. (2011). A conceptual model of intrapreneurship in the Iranian agricultural extension organization implications for HRD. Journal of European Industrial Training, 35(7), 632-657.

Kaya, D., Güzel, D., \& Çubukçu, B. (2011). Üniversite öğrencilerinin girişimcilik eğilimlerinin araştırılması: atatürk üniversitesinde bir araştırma. Kafkeas Üniversitesi İIBF Dergisi, 1(2), 76-89.

Keleş, H.N., Özkan, T., Doğaner, M., Altunoğlu, A.E. (2012). A research on determining the levels of entrepreneurship of students with an associate's degree. International Journal of Economic and Administrative Studies, 5(9), 107-118.

Kılıç, R., Keklik, B., \& Çalış, N. (2012). A study on entrepreneurship tendency of university students: Example of Bandırma Department of Business Administration. Süleyman Demirel Üniversitesi İktisadi ve İdari Bilimler Fakültesi Dergisi, 17, 423-435.

Klapper, R. (2004). Government goals and entrepreneurship education-An investigation at a Grande Ecole in France. Education + Training, 46, 127-137.

Knight, G. A. (1997). Cross-cultural reliability and validity of a scale to measure firm entrepreneurial orientation. Journal of Business Venturing, 12, 213-225.

Koh, C. H. (1996), Testing hypotheses of entrepreneurial characteristics A study of Hong Kong MBA students. Journal of Managerial Psychology, 11(3), 12-25.

Korkmaz, O. (2012). Üniversite öğrencilerinin girişimcilik eğilimlerini belirlemeye yönelik bir araştırma: bülent ecevit üniversitesi örneği, Afyon Kocatepe Üniversitesi İ̈BF Dergisi, 14(2), 209226.

Kraus, S. (2013). The role of entrepreneurial orientation in service firms: empirical evidence from Austria. The Service Industries Journal, 33(5), 427-444.

Kuratko, F. D., \& Hodgetts, M. R. (2009). Enterpreneurship theori process practice. (4 ${ }^{\text {rd }}$ ed.). Canada: Congage Learning Products.

Kuttim, M., Kallastea, M., Venesaara, U., \& Kiis, A. (2014). Entrepreneurship education at university level and students' entrepreneurial intentions. Contemporary Issues in Business, Management and Education 2013, Procedia - Social and Behavioral Sciences 110, 658-668.

Lau, P. V., \& Shaffer, A. M. (1999). Career success: The effects of personality. Career Development International, 4(4), 225-230.

Lanero, A., Vázquez, J. L., Gutiérrez, P., \& García, M. P. (2011). The impact of entrepreneurship education in European universities: An intention-based approach analyzed in the Spanish area. International Review on Public and Nonprofit Marketing, 8, 111-130.

Lamping, P., \& Kuehl, C. (2003), Entrepreneurship, (3.Edition), Trowbridge: Printice Hall International.

McKenzie, S., Ugbah, D., \& Smothers, N. (2007). Who is an entrepreneur? Is it still the wrong question?. Academy of Entrepreneurship Journal, 13, 23-43 
Öztaş, M., Kasımoğlu, M., \& Şirin, E. F. (2017). The effect of entrepreneurial personality traits of undergraduates in the area of education of physical education and sports on the entrepreneurship tendency. Journal of Human Sciences, 14(4), 4365-4382. doi:10.14687/jhs.v14i4.4918

Meredith, G. G., Nelson, R. E., \& Neck, P. A. (1982). The practice of entrepreneurship. Lagos: University of Lagos Press.

Meredith, G., Nelson, R., \& Neck, P. (1982). The practice of entrepreneurship. Geneva: International Labour Office.

Mohanty, S. K. (2005). Fundamantals of enterpreneurship. İndia: PracticeHall of İndia,

Moriano, J. A., Gorgievski, M., Laguna, M., Stephan, U., Zarafshani, K. (2012). A cross-cultural approach to understanding entrepreneurial intention. Journal of Career Development, 39(2), 162185.

Mueller, S., \& Thomas, A. S. (2001). Culture and entrepreneurial potential: A nine country study of locus of control and innovativeness, Florida International University, Miami, National Academy of Management, Journal of Business Venturing, 16(1),1-75.

Norton, Jr., W. I., \& Moore, W. T. (2006). The influence of entrepreneurial risk assessment on venture launch or growth decisions. Small Business Economics 26(3), 215-226.

Nurluöz, Ö., \& Esmailzadeh, S. (2017). Evaluating entrepreneurial characteristics and states of despair of nursing department students. EURASIA Journal of Mathematics Science and Technology Education, 13(8),4885-4896.

Öneren, M. (2012). A research on entrepreneurial tendencies of young population in Central Anatolia Region. Girisimcilik ve Kalkinma Dergisi, 7 (2), 7-28.

Öğrenci Seçme ve Yerleştirme Sistemi Kılavuzu (ÖSYS) (2016). Retrived from http://dokuman.osym.gov.tr/pdfdokuman/2015/OSYS/2015.

Özdemir, L. (2015). Kırgızistan-Türkiye Manas üniversitesi öğrencilerinin girişimcilik eğilimlerinin sosyo-demografik özellikler açısından değerlendirilmesi. Suleyman Demirel University The Journal of Faculty of Economics and Administrative Sciences, 20(1), 41-65.

Packham, G., Jones, P., Miller, C., Pickernell, D., \& Thomas, B. (2010). Attitudes towards entrepreneurship education: A comparative analysis. Education + Training, 52, 568-586.

Pillis, E., \& Reardon, K. K. (2007). The influence of personality traits and persuasive messages on entrepreneurial intention a cross-cultural comparison. Career Development International, 12(4), 382-396.

Poon, J. M. L., Ainuddin, R. A., \& Junit, S. H. (2006). Effects of self-concept traits and entrepreneurial orientation on firm performance. International Small Business Journal, 24(1), 61-82.

Ratten, V. (2011). Sport-based entrepreneurship: towards a new theory of entrepreneurship and sportmanagement. International Entrepreneurship and Management Journal, 7(1), 57-69.

Schwarz, J. E. Wdowiak, A.M. Almer-Jarz, A. D., \& Breitenecker, J.R. (2009), The effects of attitudes and perceived environment conditions on students "Entrepreneurial intent an austrian perspective". Education +Training, 51(4), 272-291.

Shane, S., \& Venkataraman, S. (2000). The promise of entrepreneurship as a field of research. Academy of Management Journal, 25, 217-226.

Shaw, E. O., Loughlin, A., \& McFadzean, E. (2005). Corporate entrepreneurship and innovation part 2: A role- and process-based approach. European Journal of Innovation Management, 8(4), 393-408.

Sternberg, R. J. (1997). Managerial Intelligence: Why IQ Isn’t Enough. Journal of Management, 23(3), 475-493.

Solmaz, S. A., Aksoy, Ö., Şengül, S., \& Sarışık, M. (2014). Tourism students’ entrepreneurial personality traits: An empirical research on undergraduate associate and bachelor's students. KMU Journal of Social and Economic Research, 16, 41-55.

Soysekerci, S., Akatay, A. (2004). Shifts In Entrepreneurship Paradigms and Profile Axes In Entrepreneurship. Turkish Journal of Social Research, 8(2), 63-77.

Şenocak, B. (1992), 2000'li Yillarn girişimcilik modeli, 3. İzmir İktisat Kongresi, 181-186, İzmir. 
Öztaş, M., Kasımoğlu, M., \& Șirin, E. F. (2017). The effect of entrepreneurial personality traits of undergraduates in the area of education of physical education and sports on the entrepreneurship tendency. Journal of Human Sciences, 14(4), 4365-4382. doi:10.14687/ihs.v14i4.4918

Şeşen, H., Basım, H. N. (2012). Demografik faktörler ve kişiliğin girişimcilik niyetine etkisi: spor bilimleri alanında öğrenim gören üniversite öğrencileri üzerine bir araştırma. Ege Academic Review, 12, 21-28.

Tays1, K., ve Canbaz, S. (2014). A Research on identifying enterpreneurship qualities and tendencies of the students of associate degree. Electronic Joumal of Vocational Colleges, 4(1), 59-67.

Titiz, T. (1994), Girişimcilik. İstanbul: İnk1lap Kitapevi.

Thompson, J. L. (2002). The world of the social entrepreneur. International Journal of Public Sector Management, 15, 412-431.

Teoh H. Y., Foo S. L. (1997). Moderating effects of tolerance for ambiguity and risk-taking propensity on the role conflict-perceived performance relationship: evidence from singaporean entrepreneurs. Journal of Business Venturing 12(1),67-81.

Todorovic, Z. M., McNaughton, R. B., \& Guild, P., (2011). ENTRE-U: An entrepreneurial orientation scale for universities. Technovation, 31(2/3), 128-137.

Tong, X .F., Tong, D. Y. K., Loy, L. C. (2011). Factors influencing entrepreneurial intention among university students. International Journal of Social Sciences and Humanity Studies, 3(1), 487-496.

Türkmen, M., İşbilir, U. (2015), Üniversite Öğrencilerinin girişimcilik eğilimlerinin sosyodemografik özellikler açısından değerlendirilmesi. Celal Bayar Üniversitesi Beden Eğitimi ve Spor Bilimleri Dergisi, 9 (2), 18-28.

Utami, C. W. (2017). Attitude, subjective norms, perceived behavior, entrepreneurship education and self-efficacy toward entrepreneurial intention university student in Indonesia, European Research Studies Journal, 20(2), 475-495.

Uygun, M., Mete, S., ve Güner, E. (2012). The Relationships between entrepreneurship intention and characteristics of young entrepreneur candidates. Organizasyon ve Yönetim Bilimleri Dergisi, 4(2),145-156.

Vázquez, J. L., Lanero, A., Gutiérrez, P., García, M. P., Alves, H., \& Georgiev, I. (2010). Entrepreneurship education in the university: Does it make the difference?. Trakia Journal of Sciences, 8, 64-70.

Wiklund, J., \& Shepherd, D. (2005). Entrepreneurial orientation and small business performance. Journal of Business Venturing 20(1), 71-91

Wu, S, Matthews, L., \% Dagher, G. K. (2007). Need for achievement, business goals and entrepreneurial persistence. Management Research News 30(12), 928-941.

Yatkın, A., \& Ölmez, M. (2011). Complementary Items of the Entrepreneurship and Entrepreneurs. e-Journal of New World Sciences Academy. 6(2), 187-201.

Yildiz, S., Kapu, H. (2012). Üniversite öğrencilerinin bireysel değerleri ile girişimcilik eğilimleri arasındaki ilişki: Kafkas üniversitesi'nde bir araştırma. Kafkas Üniversitesi İktisadi ve İdari Bilimler Fakültesi Dergisi, 3(3), 39-66.

Yüzüak, E. (2010). The factors effect on entrepreneurial intentions of female students in the universities: Canakekale Onsekiz. Mart University Biga I. I. B. F. sample. Unpublished Master's Thesis, Onsekiz Mart University Institute of Social Sciences.

Zahra, S. A. (1995). Corporate entrepreneurship and financial performance: The case of management leveraged buyouts. Journal of Business Venturing, 70(3), 225-247.

Zhao, J., Chen, L. (2008). Individualism, Collectivism, selected personality traits, and to us occupations. Journal of Vocational Behavior, 71(1), 1-22.

Zucchella, A., Scabini, P. (2007). International entrepreneurship: Theoretical foundations and practices Palgrave MacMillan: Hampshire, UK. 